\title{
Nutrient Intake and Food Consumption Pattern of Autistic Children
}

\author{
Shaly.C.M ${ }^{1}$ and Sreesna O.P ${ }^{2}$ \\ ${ }^{I}$ Lecturer, Dept.of Home Science, Vimala College, Calicut University, Thrissur,India \\ ${ }^{2}$ PG student, Dept of Home Science, Vimala College, Calicut University, Thrissur,India
}

\begin{abstract}
Autism is one of five disorders that fall under the umbrella of Pervasive Developmental Disorder $(P D D)$, a category of neurological disorders characterised by severe and pervasive impairment in several areas of development. The rate of autism has been steadily rising worldwide. There is growing evidence that nutritional therapy can really make a big difference to children with autism. The present study was carried out to assess the "Nutrient intake and food consumption pattern of autistic children". The study was conducted at various autistic centres in Thrissur. Hundred autistic children between the age group of 4-12 years were selected for the study. An interview schedule was given to the parents of the selected subjects to collect relevant data regarding socio- economic status of the families, anthropometric measurements, health history of the mothers and child, feeding behavioural problems, nutrient intake and food consumption pattern. Based on the findings of the present it can be concluded that nutritional inadequacies are more common in autistic children. Feeding behavioural problems such as picky eating behaviour, refusal behaviour and food jags are the major reasons for the nutritional inadequacies in autistic children.
\end{abstract}

KEYWORDS: autism, anthropometric measurements, feeding behavioural problems, nutrient intake

\section{Introduction}

Autism is a complex neurodevelopment disability that typically, but not always, appears during the first 3 years of life and impacts the areas of social interaction and communication skills ${ }^{1}$.Both children and adults with autism typically show difficulties in verbal and nonverbal communication, social interactions, and leisure or play activities. Autistic symptoms gradually begin after the age of six months, become established by age two or three years, and tend to continue through adulthood, although often in more muted form. The most common symptoms include difficulties in speech, abnormalities of posture or gesture, problems with understanding the feelings of others, sensory and visual misperceptions, sleeping disturbances, gastrointestinal dysfunction, fears and anxieties. The prevalence of autism has increased precipitously roughly 10 -fold in the past 40 years yet no one knows exactly what caused this dramatic rise. ${ }^{2}$ No single biological cause for autism spectrum disorders has been identified, and it is believed that there are numerous aetiologies, including a strong genetic component.

There is growing evidence that nutritional therapy can really make a big difference to children with autism. Many of the autistic children have severely disrupted digestion due to prolonged courses of antibiotic drugs for autism treatment and other illness. Broad-spectrum antibiotics kill good as well as bad bacteria in the gut; it can cause bowel irregularities and many gastrointestinal problems in autistic children especially constipation, diarrhoea, abdominal pain, vomiting etc. Disrupted digestion potentially lead to allergies, it would also affect the development of their brains and disturb their vision. Both brain differences and visual defects have been detected in autistic children.

Majority of the autistic children are picky eaters or have selective eating behaviours. This creates more nutritional problems in autistic children. Children with autism spectrum disorders have a strong preference for only one colour food or only food in particular packaging and may refuse new foods or foods with certain textures. ${ }^{3}$ Autistic children are more prone to become nutritionally inadequate due to their eating behaviours. Hence the present study was conducted to assess the Nutrient intake and food consumption pattern of autistic children

\section{Materials And Methods}

Hundred autistic children between the age group of 4-12 were selected from Shoranoor Iccons Hospital, Model girls higher secondary school, SarvaShikshaAbhian Centre Mala, SisukshemaSamithiAutism Centre and Reach Swasraya Autism Centre. An interview schedule was used for collecting the information regarding the socio- economic status of the families, anthropometric measurements, health history of the mothers and children, feeding behavioural problems, nutrient intake and food consumption pattern. In this study the quantitative aspects of consumption was studied by 24 hour recall history and qualitative aspects was studied with the use of a food frequency questionnaire. The results were statistically analysed. T- Test was used for 
analyzing mean nutrient intake of the subjects and $\mathrm{z}$ score was used for analyzing anthropometric measurements.

\section{Results And Discussion}

\subsection{Socioeconomic status of the families}

A total of 100 children including 23 boys and 7 girls in 4-6 years, 23 boys and 10 girls in 7-9 years and 26 boys and 11 girls in 10-12 years were included in this study Socioeconomic status of the subjects revealed that majority ( 66 per cent) of the subjects belonged to the Hindu community. In this study nuclear family ( 58 per cent) was predominant than joint family ( 42 per cent). The data regarding economic status revealed that the main sources of income of the majority of the families were from business ( 32 per cent) and govt. job ( 28 per cent). Eighty seven per cent of the subjects belonged to middle income group and 11 per cent of the subjects belonged to low income group.

\subsection{Health history of the mothers}

The birth order of the subjects revealed that 55 per cent of the subjects were the first child of the family and 45 per cent of the subjects were second born child of the family.

Conception age of mothers revealed that 14 per cent of the mothers conceived between the age group of 31-35 years and 6 per cent at the age greater than 35 years. Fifty per cent of the mothers experienced complications during pregnancy. The most common complications were infections, pregnancy induced hypertension, gestational diabetes and others. Thirty three per cent of the subjects had problems during delivery. The most common problems were bleeding, preterm caesarean delivery and amniotic fluid consumption by foetus.

\subsection{Health history of the subjects}

Majority of the subjects ( 76 per cent) had mild degree of autism. Forty per cent of the subjects diagnosed the autism between 1-2 years. In the selected subjects 29 per cent of the subjects had problems while going to sleep or during sleep. Eight per cent of the subjects slept less than 4 hours. Majority of the subjects (69 per cent) took both allopathic treatment and speech therapy and 48 per cent of the subjects took vitamin and mineral supplementation.

\subsection{Feeding behavioural problems}

Ninety per cent of the subjects had feeding behavioural problems. Among this the most common feeding behaviours seen were picky eating behaviour, refusal behaviour and food jags.

\subsection{Anthropometric measurements}

Height and weight measurements of the children taking age and sex in to consideration were expressed in terms of $\mathrm{Z}$ scores recommended by WHO. The data regarding nutritional status according to BMI for age revealed that, in the age group of 4-6 years 65.2 per cent of the boys and 85.7 per cent of the girls were found to have normal BMI for age. Where as in 7-9 years 78.3 per cent of the boys and 90 per cent of the girls found to have normal BMI for age. In the age group of 10-12 years 100 per cent of the girls and 80.8 per cent of the boys had normal BMI for age.

Table 1 Nutritional status according to BMI for age

\begin{tabular}{|c|c|c|c|c|c|c|c|c|c|c|c|c|}
\hline \multirow{3}{*}{ Status } & \multicolumn{6}{|c|}{ Boys } & \multicolumn{6}{|c|}{ Girls } \\
\hline & \multicolumn{2}{|c|}{ 4-6 years } & \multicolumn{2}{|c|}{ 7-9 years } & \multicolumn{2}{|c|}{$10-12$ years } & \multicolumn{2}{|c|}{ 4-6 years } & \multicolumn{2}{|c|}{ 7-9 years } & \multicolumn{2}{|c|}{$\begin{array}{l}10-12 \\
\text { years }\end{array}$} \\
\hline & No & $\%$ & $\begin{array}{l}\mathbf{N} \\
\mathbf{0}\end{array}$ & $\%$ & No & $\%$ & $\begin{array}{l}\mathbf{N} \\
\mathbf{0}\end{array}$ & $\%$ & $\begin{array}{l}\mathbf{N} \\
\mathbf{0}\end{array}$ & $\%$ & No & $\%$ \\
\hline Normal & 15 & 65.2 & 18 & 78.3 & 21 & 80.8 & 6 & 85.7 & 6 & 90 & 11 & 100 \\
\hline Moderate & 5 & 21.7 & 2 & 8.7 & 2 & 7.7 & 1 & 14.3 & 3 & 30 & 0 & 0 \\
\hline $\begin{array}{c}\text { Severe } \\
\text { under } \\
\text { weight }\end{array}$ & 3 & 13.0 & 3 & 13.0 & 3 & 11.5 & 0 & 0 & 1 & 10 & 0 & 0 \\
\hline Total & 23 & 100 & 23 & 100 & 26 & 100 & 7 & 100 & 10 & 100 & 11 & 100 \\
\hline
\end{tabular}

\subsection{Food consumption pattern}

Seventy eight per cent of the subjects were non vegetarians. Majority of the subjects (71 per cent) followed three meal patterns. Twenty eight per cent of the subjects had the habit of skipping meals. Most of the children (17 per cent) skipped meals due to dislike for foods. Majority of the subjects ( 75 per cent) liked eating 
foods from outside. Consumption of junk foods was found to be higher in the selected subjects. The mostly preferred junk foods were salted chips, soft drinks, sandwich and burger.

Frequency of consumption of food items revealed that cereals and other vegetables were found to be the most frequently used food items. Moderately used foods include pulses, fats and oils, sugar and jaggery. Food items like green leafy vegetables, roots and tubers, fruits, milk, egg and fish were found to be in less frequently used food items. Curd, cheese, chicken, beef and pork were included in least frequently used foods

Table 2: Food intake of the subjects

\begin{tabular}{|c|c|c|c|c|c|c|c|c|}
\hline \multirow[b]{4}{*}{ Food items } & \multicolumn{8}{|c|}{ Age group } \\
\hline & \multirow{2}{*}{\multicolumn{2}{|c|}{ 4-6 years }} & \multirow{2}{*}{\multicolumn{2}{|c|}{$7-9$ years }} & \multicolumn{4}{|c|}{ 10-12years } \\
\hline & & & & & \multicolumn{2}{|c|}{ Boys } & \multicolumn{2}{|c|}{ Girls } \\
\hline & $\begin{array}{l}\text { Mean } \\
\text { food } \\
\text { intake }\end{array}$ & $\begin{array}{l}\text { Percenta } \\
\text { ge } \\
\text { ofRDA } \\
\text { met }\end{array}$ & $\begin{array}{l}\text { Mean food } \\
\text { intake }\end{array}$ & $\begin{array}{l}\text { Percenta } \\
\text { ge of } \\
\text { RDA met }\end{array}$ & $\begin{array}{l}\text { Mean } \\
\text { food } \\
\text { intake }\end{array}$ & $\begin{array}{l}\text { Percent } \\
\text { age of } \\
\text { RDAm } \\
\text { et }\end{array}$ & $\begin{array}{l}\text { Mean } \\
\text { food } \\
\text { intake }\end{array}$ & $\begin{array}{l}\text { Percent } \\
\text { age of } \\
\text { RDA } \\
\text { Met }\end{array}$ \\
\hline Cereals & $\begin{array}{c}100 \\
(120)\end{array}$ & 83 & $\begin{array}{c}150 \\
(180)\end{array}$ & 83 & $\begin{array}{c}181 \\
(240)\end{array}$ & 75 & $\begin{array}{c}198 \\
(300)\end{array}$ & 66 \\
\hline Pulses & $\begin{array}{c}31 \\
(30)\end{array}$ & 103 & $\begin{array}{c}33 \\
(60)\end{array}$ & 55 & $\begin{array}{c}34 \\
(60)\end{array}$ & 57 & $\begin{array}{c}32 \\
(60)\end{array}$ & 53 \\
\hline $\begin{array}{l}\text { Green leafy } \\
\text { vegetables }\end{array}$ & $\begin{array}{c}23 \\
(50)\end{array}$ & 46 & $\begin{array}{c}10 \\
(100)\end{array}$ & 10 & $\begin{array}{c}15 \\
(100)\end{array}$ & 15 & $\begin{array}{c}18 \\
(100)\end{array}$ & 18 \\
\hline $\begin{array}{l}\text { Roots and } \\
\text { tubers }\end{array}$ & $\begin{array}{c}65 \\
(100) \\
\end{array}$ & 65 & $\begin{array}{c}30 \\
(100)\end{array}$ & 30 & $\begin{array}{c}90 \\
(100)\end{array}$ & 90 & $\begin{array}{c}92 \\
(100)\end{array}$ & 92 \\
\hline $\begin{array}{l}\text { Other } \\
\text { vegetables }\end{array}$ & $\begin{array}{c}72 \\
(100)\end{array}$ & 72 & $\begin{array}{c}66 \\
(100)\end{array}$ & 66 & $\begin{array}{c}70 \\
(200)\end{array}$ & 35 & $\begin{array}{c}70 \\
(200)\end{array}$ & 35 \\
\hline Milk & $\begin{array}{c}40(500 \\
)\end{array}$ & 8 & $91(500)$ & 18 & $33(500)$ & 7 & $9(500)$ & 2 \\
\hline Fruits & $\begin{array}{c}61 \\
(100)\end{array}$ & 61 & $\begin{array}{c}38 \\
(100)\end{array}$ & 38 & $\begin{array}{c}25 \\
(100)\end{array}$ & 25 & $\begin{array}{c}47 \\
(100)\end{array}$ & 47 \\
\hline Sugar & $12(20)$ & 60 & $12(20)$ & 60 & $17(35)$ & 49 & $15(35)$ & 43 \\
\hline Fats and oils & $13(25)$ & 52 & 14(30) & 46 & $13(35)$ & 37 & $15(35)$ & 43 \\
\hline $\begin{array}{l}\text { Egg/meat/ } \\
\text { chicken/fish }\end{array}$ & $15(50)$ & 15 & $35(100)$ & 35 & $30(100)$ & 30 & $25(100)$ & 25 \\
\hline
\end{tabular}

Ref: ICMR (2011) RDA of nutrients is given in brackets.

\subsection{Nutrient intake of the subjects}

In all the age groups the data regarding nutrient intake of the subjects revealed that B vitamin intake was found to be very less when compared to the RDA value. B vitamins are essential vitamins for the neurological development. Nutrition is one of many factors that affect brain development and functioning, B vitamins and $\mathrm{n}-3$ polyunsaturated fatty acids are two of the most promising and widely studied nutritional factors for brain development. ${ }^{4}$ (van de Rest et al., 2012).

The intake of vitamin A and iron was also found to be very less due to the decreased consumption of green leafy vegetables and fruits. There is very high prevalence of iron deficiency in children with autism, which could potentially compromise further communication and behavioural impairments. ${ }^{5}$ The intake of protein was found to be greater than the RDA in all the age groups except 10-12 years, because of the higher intake of cereals, pulses and fish. The intake of calcium was found to be very less when compared to the RDA value due to the decreased consumption of milk and milk products.

\section{Conclusions}

Based on the findings of the present study "Nutrient intake and food consumption pattern of autistic children" it can concluded that faulty dietary practices, nutritional inadequacies and feeding behavioural problem are more common in autistic children.

\section{References}

[1] Autism Society of America, Autism and intellectual disability: Two sides of the same coin. American Journal of Medical Genetics, 160(2), 2012,89-90.

[2] M.D. Kinga, and P.S. Bearmanb,Socioeconomic status and increased prevalence of autism in California, Sage journals. American Sociological Review, 76(2), 2011, 320-346.

[3] W.H.Ahern, T. Castine, K. Nault, and G. Green, An assessment of Food Acceptance in children with Autism or Pervasive Developmental Disorder not otherwise specified, Journal of Autism and Developmental Disorders, 31(9),2001,505-511.

[4] 4 O. Van de Rest, W.A.Van Hooijdonk, A. Eilander, and C.P. Lisette, B Vitamins and n-3 Fatty Acids for Brain Development and Function: Review of Human Studies, Annals of Nutrition and Metabolism,60(4), 2012, 272-292.

[5] A.Latif, P.Heinz, and R. Cook,(2002). Iron Deficiency in Autism and Asperger Syndrome, Autism SAGE Journals, 6(1), 2002, 103114. 